\title{
Platform mobilities and the production of urban space: Toward a typology of platformization trajectories
}

DOI:

$10.1177 / 0308518 \times 19896801$

\section{Document Version}

Accepted author manuscript

Link to publication record in Manchester Research Explorer

\section{Citation for published version (APA):}

Stehlin, J., Hodson, M., \& Mcmeekin, A. (2020). Platform mobilities and the production of urban space: Toward a typology of platformization trajectories. Environment \& Planning A. https://doi.org/10.1177/0308518X19896801

\section{Published in:}

Environment \& Planning A

\section{Citing this paper}

Please note that where the full-text provided on Manchester Research Explorer is the Author Accepted Manuscript or Proof version this may differ from the final Published version. If citing, it is advised that you check and use the publisher's definitive version.

\section{General rights}

Copyright and moral rights for the publications made accessible in the Research Explorer are retained by the authors and/or other copyright owners and it is a condition of accessing publications that users recognise and abide by the legal requirements associated with these rights.

\section{Takedown policy}

If you believe that this document breaches copyright please refer to the University of Manchester's Takedown Procedures [http://man.ac.uk/04Y6Bo] or contact uml.scholarlycommunications@manchester.ac.uk providing relevant details, so we can investigate your claim.

\section{OPEN ACCESS}




\title{
Platform mobilities and the production of urban space: \\ Toward a typology of platformization trajectories
}

\begin{abstract}
The past decade has seen an explosion in what is popularly known as the "sharing economy," perhaps most visibly in the realm of transport. Digital "shared mobility" platforms like Uber, Car2Go, and Mobike, as well as emerging, more sophisticated "mobility-as-a-service" platforms which coordinate multiple discrete services into a single portal, have risen to prominence as modes of reworking everyday urban transport in cities of North America, Europe, and East Asia in particular. This paper aims to explore the driving forces and concrete expressions of this platformization of urban mobility, as a particularly diverse and volatile component of a broader platform urbanism. Based on the construction and analysis of a database consisting of 200 urban mobility platforms drawn from across the globe, we highlight five key trajectories of platform formation, focusing on the firms, institutions, and social interests that have fueled the growth of this sector, and the modes of infrastructural organization, spatial formation, and governance that they entail. We further highlight the fragility of this particular form of "spatial fix," and the prospects for a more redistributive form of platform urbanism. We conclude by reflecting on implications for future research.
\end{abstract}




\section{Introduction}

The past decade has seen an explosion in the digital mediation of everyday urban life, particularly transport. Venture capital has poured into a wide range of smartphone-based mobility services like ride-hailing, car-, bicycle-, and scooter-sharing, journey planning, and integrated "mobility-as-a-service" (MaaS) systems. Meanwhile, cities facing fiscal austerity, rising congestion, a mandate to reduce carbon emissions, and an onslaught of speculative investment turn to these innovations as a future transport strategy. Proponents hail mobility platforms - digital infrastructures that mediate transactions between transport providers and passengers (Srnicek, 2016) — as a way to more efficiently and sustainably "share" existing assets (Sundarajan, 2016), while critics charge that such platforms represent a new horizon of monopolistic data extraction (Thatcher et al., 2016). Whether framed as positive or negative, however, the digital mediation of a widening range of everyday practices through the platform economy has profound implications for the organization of urban life, and in particular how platformization intersects with durable socio-spatial inequalities, as well as the prospects for a more redistributive approach to platform urbanism.

In this paper, we present a preliminary analysis of a qualitative database of 200 digital mobility platforms we generated from August 2018 to June 2019. We argue that while major firms like Uber or Didi Chuxing are the best known and most widely critiqued of these, the actually existing landscape of platform mobilities is extraordinarily variegated (Peck and Theodore, 2007), characterized by a dialectic of proliferation, mutation, and consolidation, spurred by competing and contradictory logics, and fueled by enormous but uneven capital inflows. This diversity, and the potential futures opened by certain kinds of platform experiments, is often subsumed within narratives of a data-driven Leviathan in the making (Gibson-Graham, 2006). At the same time, the profound unevenness of platformization both within and across cities, dismal prospects for profitability, highly contested governance mechanisms, and concerns about congestion, surveillance, and waste cast doubts on the long-term viability of the sector-even those experiments whose logics differ from the dominant extractive model. In this paper, to capture this heterogeneity, we present a heuristic typology of trajectories of platform formation, rather than the formal features of the platforms themselves, focusing on the interests, institutions, and investment strategies these platforms reflect within the changing political economy of transport. We follow this with an assessment of key issues related to the infrastructural, spatial and governmental embedding of these platforms in urban space, before concluding with implications for future research.

\section{Situating the platformization of mobility}

The platformization of mobility results from the convergence of multiple sociotechnical and political-economic transformations manifesting unevenly across the global urban realm. The first of these is the stubborn unsustainability of the transport sector, which accounts for roughly $25 \%$ 
of all carbon emissions globally, but is highly uneven across multiple scales (International Energy Agency, n.d.). At the urban scale, parallel anxieties about traffic congestion, pollution, and obesity are compounding these issues and spurring attempts to reduce private automobility in the North Atlantic "core" and arrest its rise in "emerging economies" like China and India (Hecker et al., 2018; Pojani and Stead, 2017; The Economist, 2018). Nevertheless, there is wide recognition that in the future auto manufacturers can no longer rely on sales to individual consumers (Hanna et al., 2015). The only alternative appears to be movement away from personal vehicles and toward using the existing road network more sustainably, particularly for "last-mile" connections to mass transport hubs. Meanwhile, the "green premium" that cities adopting this approach enjoy in the form of rising land values and investment has raised concerns about the formation of "ecological enclaves" embedded within a wider car-dependent urban fabric (Hodson and Marvin, 2010).

The parallel development of the "geoweb" linking spatial information to online content (Elwood and Leszczynski, 2011) and the rise of location based services enabled by widespread smartphone adoption (Wilson, 2012) forms a second set of essential conditions. Location-based services facilitate the urbanization of what has been variously termed "platform capitalism" (Srnicek, 2016), the "platform society" (van Dijck et al., 2018), and "surveillance capitalism" (Zuboff, 2015) - a mode of accumulation organized around the capture, algorithmic processing, and monetization of user data. Archetypal platforms like the "big four" (Amazon, Apple, Facebook, and Google) have several common features: they intermediate multi-sided interactions and transactions through an opaque algorithmic architecture that cross-subsidizes free services with premium features and captures rents through network effects (Langley and Leyshon, 2017; Srnicek, 2016). With the deepening of the geospatial dimensions of the platform economy has come the increasing co-constitution of platform structures and urban space: a platform urbanism. This turn both reorients discussions of platform capitalism around the material unevenness of the urban and places the constantly mutating platform world at the center of understanding contemporary urban transformations.

Platform urbanism suggests an emergent mode of "smart city" development. As Sarah Barns has argued, a key feature of platform urbanism is the impetus to convert urban space into a ubiquitously instrumented, self-adjusting "real-time city" (Kitchin, 2014) whose raw material is the data "sweat" (Gregg, 2015) generated by everyday practices, algorithmically processed and made legible as an object of intervention (Barns et al., 2017). Thus, where Cisco and IBM have advanced top-down "urban operating systems" in partnership with municipal governments (Barns, 2016; Marvin and Luque-Ayala, 2017; Wiig, 2016), platform urbanism speaks to a shift toward more a governmental (in the Foucaultian sense) mode of smartness: constructing a milieu within which the free play of "natural" tendencies facilitates "action at a distance" (Foucault, 2009). At the same time, because it is also a regime of accumulation, this "free play" generates new data of potentially strategic value. Urban mobility is a particularly fecund source of data, 
because of the relative contingency and autonomy of mobility practices (i.e. not dictated by employers or the state). This dependence on the urban lifeworld as a data source raises what Thatcher et al. (2016) call "data colonialism," or the generation, enclosure, and proprietary algorithmic processing of user data, from which users themselves are alienated. This is only possible because cities are already massive bundles of positive externalities, nodes linking different infrastructure networks, and large consumer markets all at once. Furthermore, the data accumulation regime does not just passively harvest, but actively fuels data production. As Sadowski (2019) points out, data is not just "out there" waiting to be collected, but a form of capital: a production apparatus that valorizes raw information through algorithmic processing. Urban heterogeneity, and the need to render different places and practices commensurable, increases the strategic value of this form of capital.

More broadly, the platformization of mobility is a response to the increasingly global "wall of money" (Leininger, 2018) and localized conditions of pervasive urban austerity resulting from the neoliberal "roll-back" of local state functions, transport in particular (Peck and Tickell, 2002). This creates pressure to deliver services more entrepreneurially through market mechanisms (Harvey, 1989), and in response, approaches to transport planning have shifted from public service to development stimulus (Grengs, 2005; Schwanen, 2016), leading to the "residualization" of public services for the rest (Graham and Marvin, 2001). Thus, voids both between and beyond the scales of existing mass transport services, which have historically been filled by more flexible modes like bicycling, walking, taxis, jitneys, and private cars, have grown at a time when state capacity (both fiscal and political) to fill them has waned. In response, leaders in shaping future mobility policy argue that "code is the new concrete" (Crist, 2018), setting a standard for instantaneous infrastructure - implicitly without the need to physically upgrade the existing infrastructural base - that only the market can deliver. The result is an interstitial platform infrastructure dependent on existing (often publicly funded) infrastructures like road networks, sidewalks and other public spaces, existing mass transport systems, telecommunications, and GPS. This turn represents a further neoliberalization of transport, beyond the outsourcing of service delivery to public-private partnerships (Siemiatycki, 2011). Ironically, as so-called market-based solutions, platforms, in the relentless, venture capital-fueled pursuit of growth, are no more financially sustainable than publicly funded transport (Kanter, 2019); in effect, this wave of marketization establishes not fiscal rectitude but rather private monopoly over emerging forms of mobility for favored populations and places.

But this "roll-out" neoliberalization (Peck and Tickell, 2002) also has a governmental component (Brown, 2015), producing new kinds of urban practices as well as the means to efficiently manage them. Platform mobility tends to both presuppose and constitute a certain kind of subject distinct from the self-maximizing homo economicus: the perfectly flexible mobility consumer guided by a self-optimizing algorithm to which they must remain attuned and responsive. For example, journey planning apps, particularly those that link different travel modes together, 
demand that the user be able to quickly switch itineraries based on real-time performance data. A number of "micro-mobility" platforms (mainly bicycles and e-scooters) have adopted a "gamified" approach to molding user behavior, incentivizing "rebalancing" trips and proper parking behavior in an attempt to reduce labor inputs. This mandatory flexibility is even more pronounced in the labor process, in which redistribution, charging, and repair is often done, as with Uber and related platforms, by piece-rate contractors in cutthroat, real-time competition (Lorenz, 2018). The new regimes of mobility that platforms represent thus reconfigure not only transport services but also the practices and geographies that underpin them.

We focus on mobility as a distinct vector of platformization because of its specific materiality the way that it reveals the entanglement of the platform and the city, and how it in turn sheds new light on the political economy of platforms more generally. As a number of authors have argued, mobility constitutes social life (Cresswell, 2010; Sheller and Urry, 2006) but is also a key dimension of its sociospatial inequality —what Doreen Massey calls "power-geometry" (1994). Mobility is necessarily frictional, materially obdurate, and embedded in places, rhythms, and well-worn spatiotemporal grooves under conditions of uneven geographical development (Edensor, 2011; Smith, 1984): a relational ensemble of "mooring" and "liquidity" (Hannam et al., 2006). Mobility platform firms exploit this dialectic, using primarily digital "fixes" to launch much faster than conventional infrastructure, but the platformization of mobility does not manifest equally everywhere, because these firms still inherit local political economies, regulatory structures, scales of existing infrastructure, and obdurate built environments that shape capacities for movement (Hommels, 2005). Thus, while often framed as a smooth rollout of pervasive algorithmic control, the friction of this digital/urban interface poses a limit to be overcome technologically (Harvey, 2006), rendering mobility a potent entry point through which to more broadly reorganize urban services and extract new sources of value from their intermediation.

The platformization of mobility also offers a new lens into broader debates over ongoing urban transformations, one which cuts across older binaries of global North and South. These debates, which center on Lefebvre's thesis that the urban world is superseding the industrial and becoming "planetary," have been particularly fierce (Brenner and Schmid, 2015; Derickson, 2018; Oswin, 2018; Robinson and Roy, 2016; Storper and Scott, 2016). Platform mobilities cut across these debates, constituting what we might call "ordinary" (Robinson, 2006) forms of becoming planetary, in which everyday practices are, through digital communications and financial infrastructures, articulated into planetary ensembles of data capital. The process of platformization of mobility tends toward both the increasing informalization of infrastructure, particularly but not exclusively in global North cities, and the increasing formalization of more ad-hoc mobility infrastructures in the global South, often through the same platforms (Silver, 2014). This suggests not a "convergence" in a simple sense, but the articulation of disparate 
practices into a network of digital infrastructures, organized through ubiquitous instrumentation rather than massive capital investments, stretching unevenly across the globe.

Finally, these factors combine to produce a landscape of mobility platforms that is both extraordinarily variegated (Peck and Theodore, 2007) and fundamentally diverse (GibsonGraham, 2006). While these epistemological perspectives may seem at odds, we see them as complementary. The increasingly global network of platform experimentation, with particular centers of gravity in California, Northern Europe, and coastal China, functions as an unevenly structured totality that articulates together distinct institutional sources of profit-seeking capital, competitive strategies, and experimental modes of regulatory reform, leading to different styles of platform formation, and in many cases geographically distinct approaches within the same platform. This is the variegated dimension. But platformization as technique, particularly its "lean" technological basis, has also opened up spaces, albeit thus far limited, for more noncapitalist coordination of public services by local states and cooperatives-“diverse economies" (Gibson-Graham, 2006) - that do not figure in many critiques of platform capitalism.

Furthermore, because platforms themselves convert heterogeneous practices, across scales and social structures, into commensurable data, they are also internally variegated and diverse. In what follows, we trace both this variegation and diversity, while stressing that the uncertain future of the platform bubble, driven by vast venture capital inflows at a high "burn rate" (Nolan, 2015), may in the event of collapse destabilize the diversity of other-than-capitalist experiments in platformization.

\section{Toward a typology of platformization trajectories}

We draw on a preliminary analysis of a qualitative database of 200 mobility platforms, both active and no longer in operation, that we compiled between August 2018 and June 2019. We collected the following information: their funders and promoting agencies, launch date, and founders; the service, technology, and data produced (or the 'stack,' for Bratton, 2015); and their spatial tendencies, relation to other infrastructure, and implications for urban governance. ${ }^{1}$ For platforms funded with venture capital (the majority), these details were collected using the search engine Crunchbase. But in recognition that venture capital networks are skewed towards startups in the North Atlantic and global East, we supplement this data with industry press such as TechCrunch, Smart Cities Dive, Business Insider, Digest Africa, Technode, and The Straits Times, corporate press releases, social media sources, and data from the Apple and Google application stores. We also analyzed the investment history of the 25 most frequent investors appearing in the database as one of the top five (tabulating manually for investors that do not appear in the Crunchbase database), in order to develop an understanding of how investments in mobility platforms fit within their wider strategies.

Analytically, we focus on the social interests (venture capital firms, corporations, and banks, but also social enterprises, governments, and cooperatives) that engage in platform development, in 
keeping with a longstanding focus in heterodox political economy on investment as the driving force of capital accumulation (Storper and Walker, 1989). We do this in order to capture both the dynamic and evolutionary nature of platformization as a process, and the varying strategies underpinning different platforms that may appear in formal terms quite similar. At the same time, we recognize that the platforms themselves are co-constituted by the places where they are deployed and the everyday practices in which they are embedded. Based on our analysis, we developed a heuristic typology of five basic blocs, which we refer to as data capital, infrastructural capital, motordom, public capital, and communities of consciousness. They exhibit the following general platformization trajectories.

\section{Fig. 1: Platformization trajectories table here}

\section{Platformization as networked accumulation}

The most well-known platformization path is the "move fast and break things" or "disruption" approach, characterized by fast-moving firms, supported with large infusions of venture capital, exploiting gaps in the interstices of existing transportation infrastructures and attacking incumbent firms and business models - the archetype of which is Uber. This path is dominated by what we call the data capital bloc (Sadowski, 2019), primarily venture capital firms and investment banks focused on high technology, as well as the venture arms of conglomerates like Tencent and Alibaba. Their accumulation strategies involve broad investment across a range of digital services and startups, of which mobility is a small part, and their assets are substantially digital, and particularly concentrated in data and intellectual property. In less digitally connected parts of the global South, IT firms like Siemens and Qualcomm are also involved in platform development, which represents an opportunity to further nurture demand for their services.

A common feature of these firms is the "sweating" (Lacy and Rutqvist, 2015) of existing assets (taxis, personal cars, motorbikes, etc.) by incorporating them into a platform that becomes an increasingly large ecosystem of urban consumption generated through the network effects of app adoption, only possible because of its deployment of already existing assets, while the firm positions itself as an intermediary rather than an owner of capital or employer of labor. A pioneer of this "super app" approach, Indonesia's GO-JEK launched in 2010 as an Uber-like service for moto-taxis, but subsequently expanded into food delivery, digital wallet, personal services, and even bill payment and tax return processing (Sender, 2019). Similarly, China's WeChat, backed by Tencent, began as a social media platform and added games, mobile payments, ride-hailing, and many other services (Huang, 2017). Uber, Lyft, Grab, and others have followed this approach, adding food delivery, shared bikes and scooters, and mass transport options, as well as pivoting toward selling fleet management services to third parties, as a way to expand the range of services accessed within the app (Bliss, 2018). Thus, it is the data, platform engagement, and network effects of the use of these vehicles that is their value proposition, not the physical capital itself. 
Firms on this trajectory, particularly ride-hailing but also dockless bike and scooter share, rely on both regulatory indeterminacy and vast shadow subsidies for their ability to rapidly launch and "blitzscale" (Brail, 2017; Sullivan, 2016). Uber has famously battled a wide range of governments, from the local to the national, over permitting, driver background checks, and worker categorization, and other firms like Ofo have followed its regulatory playbook (Henley, 2017; North American Bikeshare Assocation, 2018). This approach tends to incur huge operating

losses. American competitor Lyft, as well as major Asian rivals Didi Chuxing, Grab, and Ola all lose money at a comparable rate, if a lower volume (Lee, 2016; Shameen, 2017; The Economist, 2019). These losses effectively require a future monopoly, prompting expansion into other services and modes of travel, or the further commercialization of their only assets - datathrough targeted in-app advertising, partnerships with other platforms, and acquisition of rivals to increase data complementarity (Somerville, 2019) in order to restore profitability. In this respect, data capital is relatively agnostic regarding the actual provision of mobility.

\section{Platformization as infrastructural thickening}

A less widespread but no less important pattern is one of infrastructural "thickening" led by incumbent transport corporations, which we call infrastructural capital. These firms have tended to pursue platformization as a means reacting to the disruption caused by data capital by extending their existing strengths in fixed-route transport.

Two major patterns can be discerned within this trajectory. The first is experimentation with "first/last mile" mobilities linked to existing mass transport networks. Examples of this approach include: Deutsche Bahn's bike- and car-sharing service Flinkster, launched in 2001; Spanish infrastructure firm Acciona's scooter sharing platform Acciona Mobility; and French infrastructure firms Keolis's investments in Via, a dynamic shuttle platform. But perhaps understandably, infrastructural capital has been less quick to adopt platform approaches, as they compose a smaller portion of their overall business.

A more thoroughgoing platformization pattern can be found with the pronounced shift toward investment in "mobility-as-a-service" (MaaS) platforms designed explicitly as a comprehensive alternative to car ownership. Whim, an app developed by Finnish startup MaaS Global Oy with investment from French infrastructure firm Transdev, is an all-in-one "Netflix of transport" (Reid, 2019), a demand-responsive, subscription-based mobility app that integrates the existing public transport network with ride-hailing services, taxis, carpooling, flexible shuttles, and shared rental cars and bicycles. This matches Transdev's future expansion goals in the area of "personal, autonomous, connected, electric" (Leriche and Teale, 2018). As of early 2019, Whim had rolled out in Helsinki, Antwerp, and Birmingham, UK, with expansion plans for North America and East Asia. Similarly, Deutsche Bahn's Ioki, a wholly owned subsidiary rather than a separate startup, offers on-demand transport connected to Deutsche Bahn's services in 
Hamburg, Frankfurt, rural Rhineland, and Berlin's science park as part of its "strong rail system" plan (Deutsche Bahn, 2019). Both Whim and Ioki were also developed through partnerships with multiple levels of government, existing public transport infrastructure services, and state innovation funds (see "Public Capital" section below), representing a more long-term orientation than "move fast and break things."

\section{Platformization as life extension}

A similar strategy that builds on existing strengths is pursued by the collective interests we call motordom (Norton, 2011), which all share a path dependence related to the system of automobility (Sheller and Urry, 2000). Motordom encompasses auto manufacturers, rental car companies, car insurers, parking management firms, and motoring clubs within a general strategy aimed at guaranteeing the utilization of their existing capital bases. For nearly all of motordom, the path forward lies in a "pivot" towards selling mobility rather than vehicles (Business Wire, 2016), both through car-sharing platforms and in the longer term developing autonomous vehicles and platforms to manage autonomous fleets.

Like infrastructural capital, motordom's investments have been more commonly made through internally financed subsidiaries or joint ventures. The most notable of these are "floating" carsharing fleets Car2Go (Daimler) and Reachnow/Drivenow (BMW), which merged into FreeNow, a car-sharing, ride-hailing, and charging station platform in December 2018 (Daimler North America, 2018). ${ }^{2}$ Volkswagen has developed a subsidiary, Moia, which is demandresponsive "micro-transit" platform using electric six-seater vans, and a We Share floating electric car sharing service in Berlin. Comparable services at a smaller scale have been developed by parking management firms like Spain's EYSA or Paris's Indigo. Even motoring clubs like the American Automobile Association and Austria's Österreichischer Automobil-, Motorrad- und Touring Club have developed shared vehicle schemes, including both cars and mopeds.

Some automobile interests have begun to move into startups as well, through both investments and acquisitions, but typically later in their growth paths. Toyota has funded Uber, Grab, and peer-to-peer car-sharing platform Getaround, Volkswagen invests in European Uber competitor Gett, Daimler has invested in "micro-transit" firm Via, and Ford purchased Via's now-defunct competitor Chariot. Rental car firms Europcar and Sixt invested in Car2Go and DriveNow, respectively, following the path of Avis-Budget in purchasing car sharing pioneer ZipCar in 2013. Some firms have spun off venture arms, like BMW's iVentures, branching out into location-based marketing, materials, and software that enhance its core activities. Likewise, Daimler has invested heavily in electric vehicles, on-demand parking, vehicle charging, and demand-responsive shuttle platforms. These may have initially been reactive strategies but have now become an important element of motordom's growth agenda. 


\section{Platformization as governmental fix}

A less widely hailed dimension of platform formation is the role of governments at multiple levels in taking on tasks that private capital is unable or unwilling to perform (Mazzucato, 2014). We call such interests, in general terms, public capital, which follows two broad paths: first, developing models for public platforms, and second, fostering the "take-off" conditions for private firms. ${ }^{3}$

Some precursors to this state-led innovation path can be found in Swiss and American experiments with municipal car-sharing fleets and London's Oyster Card fare integration scheme. More recently, attention has turned toward the development of public integrated route planning and ticketing platforms that have laid the groundwork for later developments in MaaS. One such example is Polygo, a project of the Baden-Wurttemburg regional government, selected in 2012 by the German Federal Ministry for Economic Affairs and Energy as a Showcase Region for Electric Mobility. Polygo brings together public (regional bus and rail) and private (carsharing, parking management, and bike- and scooter-share) transport services into a seamless ticketing platform that also included public banking, library services, recreational access, and even a booking service for meeting with local government officials, all without the need for a smartphone. In 2018, Empresa Municipal de Transporte, Madrid's public bus operator, launched a publicly owned aggregation platform, MaaS Madrid, with integrated ticketing expected in late 2019. While the public role here is more muscular, their goal is less to directly democratize mobility than to create a public "marketplace" to attract mobility platforms to participate.

Public capital also deploys resources in more of a pump-priming approach. Especially notable is Finland, whose public innovation funds have invested heavily in MaaS, particularly with the Kyyti project, a public-private partnership sponsored by Sitra, a public innovation fund for technology investment, as part of the National Growth Programme for the Transport Sector 2018-2022. The outcome of the project is a private firm which provides the technology freely to the pilot regions while selling it elsewhere. Similarly, MaaS Global (see above), a privatelyowned global export, was developed with funding from the Finnish Funding Agency for Innovation (TEKES). In 2018 the Finnish government passed the Act on Transport Services, mandating that all transport services make their data mutually available through a single data interchange (Ministry of Transport and Communications, 2018). This aptly illustrates the type of strategy outlined by Barns, in which the municipal state optimizes regulations for private-sector platform development; in effect, the city becomes a public platform for developing private platforms (2016).

These "laboratory"-like approaches are also pursued by state-supported business accelerators, which receive support from internet and telecommunications firms like Google and Qualcomm, particularly in places where startup networks are less robust. Examples include Dar es Salaam, Tanzania's Dar Teknohama Business Accelerator, which promoted boda boda (moto-taxi) and 
bajaj (3-wheeled taxi) app Twende before it was acquired by telecom firm Tigo, and the Gauteng City Region Innovation Hub in Johannesburg, South Africa, whose Afta Robot mini-bus platform was later supported by Ericsson and Qualcomm. This speaks to a deeper reconfiguration and localization of the developmental state through platform formation in cities previously "off the map" of the digital economy.

The tensions between these two approaches highlight the fraught position of public interventions in the platform mobility landscape. In one respect, the territorial authority of the state, and its ability to deploy non-profitseeking capital, gives it the capacity to create a framework for integrating mobility services at a local level. Such precursors as the Oyster Card were major innovations in improving mobility governance that required intricate bureaucratic maneuvering. But even the most concerted efforts at creating a public mobility platform can founder on the capacity for firms with market power - who want their own apps to be the sole mobility gateway - to opt out. A larger issue is that if private firms, whose profit motive will tend to lead them toward central areas already well serviced by transport, are the "raw material," then the coverage and accessibility of the public platform is likely to remain limited.

\section{Platformization as commoning}

The final trajectory is cooperative formation, practiced by what we call, following Turner (2008), communities of consciousness. Cooperative platforms would appear to fulfill the hopes many scholars and practitioners initially had for the sharing economy before it was taken over by monopolistic firms (Scholz, 2016; Taylor, 2015). They also rely on the political commitments of their members, rendering them more fragile, contextually specific, and unevenly distributed. Cooperative platforms tend to be informed by both socialist/anarchist and libertarian ideals; the former tend to be cooperatively owned platforms governed by direct democracy and operating at a fairly localized scale, while the latter may be spatially quite distributed and organized through blockchain-based technology, enabling members to evade state currencies, enable market trust, and prevent monopoly.

A number of collectively-oriented platforms formed as non-profit alternatives to Uber's hegemony. Some are longstanding taxi cooperatives, but a growing number are new experiments that engage quite established actors in the solidarity economies, social enterprise, and other third sector organizations and foundations. Driver Co-op in Leeds-Bradford and CabFair in London were both initiated by the New Economics Foundation, spurred by its explicit focus on developing alternate structures for less exploitative "gig economy" work (New Economics Foundation, 2017). Montreal's Eva was developed in collaboration with the Quebec Council of Cooperation and Mutuality, a well-established cooperative federation. Others, like ride-hailing platform Lazooz, are crowdfunded, while a number of more libertarian initiatives like Swarm City are funded by the sale of blockchain-validated tokens. 
The obstacles facing the commonization of the platform economy are familiar: issues of resource access, democratic governance among distributed, voluntary participants, and the challenges of scaling beyond the local. Unlike community land trusts, where the resources needed are monopolized by the landlord class, sharing economy cooperative members essentially already own all of the platform assets. But this means that such platforms remain dependent on the existing distribution of resources, and may simply become an "ethical option" within the spectrum of platform capitalism that remains dominated by highly-capitalized behemoths like Uber. Furthermore, it is unclear how they could serve as a more coherent frame for governing mobility in a positive sense - producing better, more just, and more ecologically sound relations of movement.

\section{Infrastructures, spaces, and governance structures across trajectories}

Building on this first cut, we add an additional layer of analysis, based on the qualitative information captured in the database. We focus on how these business models are deployed through specific infrastructural, spatial, and governmental entailments - the conjunctures of how

they are urbanized in specific places. While this frame is necessarily schematic, given the size of the database, these dimensions cut across the different trajectories above to produce the enormous variegation and diversity we find in the platform world.

\section{A new infrastructural bubble}

Platform mobilities far exceed the simple digitization of urban services. This becomes evident in the massive capital inflows into nascent platforms, particularly bike and scooter sharing services, which are out of proportion to both revenues and assets. The speculative interest in mobility platforms is driven by the pressure to expand the user base and monopolize the data they generate in order to attract further investment. This strategy is costly, however. Both Uber and Lyft, top competitors in the American market, saw their stock prices slide immediately following their initial public offerings, deepening doubts about the underlying basis for their enormous valuations (Egan, 2019). The pace of overvaluation appears to be accelerating (Rushe, 2019) and proliferating through the mobility landscape, particularly the "micro-mobility" sector (Wilhelm, 2019).

This bubble logic, even when not resulting in a dramatic collapse, raises issues of long-term infrastructural reliability. The ability of platforms to rapidly launch and equally rapidly change, relocate, or close in response to adversity, over-extension, or changing political conditions makes the world of platform mobilities both extremely flexible and remarkably unstable. In 2017 and 2018, "dockless" bicycle platforms like Mobike and Ofo, and Lime were the major trend in micro-mobility, buoyed by vast inflows from Alibaba and Tencent, but by 2019 a number had 
contracted, switched into scooters, or disappeared entirely (McIntyre and Kollewe, 2019; South China Morning Post, 2018). Meanwhile, "micro-transit," a subsector of on-demand mobility using larger vehicles, was declared a failure, after Bridj, Chariot, Leap, and Loup all folded, leaving only Via, in which both Daimler and French rail operator Keolis are major investors (Schmitt, 2018). Thus, these dynamics do not just affect data capital; for example, Car2Go recently withdrew from all but just five North American cities: Montreal, New York, Seattle, Vancouver, and Washington, DC (St. John, 2019). Survival rates among public "MaaS" experiments can be low for different reasons, chiefly the stickiness of the local scale, or the failure to catalyze private sector spin-offs. Similarly, rapid appearance and disappearance of cooperative platforms is typically not due to overextension, but rather under-resourcing.

In practice, this means constant mutation. If "blitzscaling" increases the network effects of a single service, then further mutations tend to be about extending these network effects across an "ecosystem," either by diversification within the app, strategic partnerships with other platforms, or outright acquisition. In other words, these network effects remake the relationships between existing infrastructures through digital mediation, led - but not always completely determinedby the bloc most dependent on constant expansion: data capital. In many ways, the leading edge of this phenomenon is now the global East. Examples include GO-JEK, which expanded "bottom-up" from moto-taxi hailing across a vast range of personal services, and WeChat, which expanded "top-down" from social media into a mobility and services ecosystem. Each is anchored by a digital wallet and mobile payment system. Uber, Lyft, and other ride-hailing firms have attempted to follow this example, adding bike- and scooter-sharing, food delivery, and public "dashboards" to their platforms (Attoh et al., 2019). For established infrastructure and auto manufacturing firms, these mutations may be somewhat optional, since they possess a wealth of existing infrastructural and manufacturing assets, while for data capital it is likely essential for a path to profitability. In many cases, public platforms are designed from the start to be as comprehensive as possible, but public aggregators like MaaS Madrid must still react to and incorporate the mutations of private platforms into their services.

\section{The production of scale}

A deeper issue is the reconfiguration of space through platform mobilities. Following Smith (1992), platforms produce new scales of mobility that both implode and explode urban space, depending on how they articulate with existing infrastructural scales. For example, micromobility platforms tend to focus on the most high-demand markets, typically central business districts and surrounding gentrifying areas, which collapses their infrastructural scale inward (Sherriff et al., 2018), while places seeing service cuts to mass transport lie beyond the target area. Ride-hailing services, on the other hand, explode the scale of mobility outward, since their smartphone basis enables both consumers and drivers to reliably access less centrally located areas. They also have an uncertain relationship to mass transport-feeding larger transit nodes but cannibalizing less high-performing services (Clewlow and Mishra, 2017). This bodes poorly 
for improving transport through a "move fast and break things" platformization model in which infrastructural scale is a function of market logic.

Experiments like Moia or Ioki potentially disrupt this spatial inequality by creating dedicated "first/last mile" services at the edges of the existing transport network, but doing so requires working against private mobility platforms' tendency toward clustering in central locations. Mobility as a service platforms like Whim, as well as their public counterparts like MaaS Madrid, aim to unify these disparate scales of mobility through a single portal and payment system. But they may internalize the scalar contradictions between public and private service provision, rather than resolve them. For example, MaaS Madrid combines the city's extensive public bus and train system with a wide range of private platforms that thus far offer faint geographic coverage beyond the city center.

\section{Governing mobilities}

Related to the production of space is the question of governance, and what forms of control are exerted over everyday mobility through platformization. This takes two main forms. First is the issue of regulation. Platformization, particularly the "move fast and break things" approach of data capital, has provoked a variety of governmental responses ranging from rejection to acquiescence to enthusiastic promotion, and typically larger, more powerful cities are able to extract concessions, including licensing fees, specified operating zones, and data sharing requirements. But equally, firms have at times withdrawn from cities on the grounds that following such requirements is too costly. Mobility as a service firms must by necessity adopt a more collaborative approach but can still contribute to the erosion of public capacity. Public ownership offers the potential for democratic accountability, particularly concerning public policy objectives such as equitable coverage or non-commercialization of data that directly clash with profit motives. MaaS Madrid's approach may be one route to this kind of control, though agreements with larger private firms like Uber are likely difficult to enforce because of their market power.

But there is another level of control, which concerns the way that politics become embedded in technologies themselves (Winner, 1989). If the data that are needed to govern urban mobility are increasingly accumulated, processed, and packaged by private entities, particularly evident with route planning apps like CityMapper and Uber's "Uber Movement" dashboard, then democratic governance of infrastructure planning is likely to be eroded. Furthermore, if assumptions about accessibility, coverage, and so on become integrated into MaaS platforms at the level of software, with potentially adverse effects, then public ownership will have a limited effect over the practices of each individual service. Thus, popular narratives of the struggle for control over the platform economy, which often focus on jurisdictions' regulation of the firms themselves, miss the forms of algorithmic control that cross the boundaries of public and private, and the shift to biopolitical governance that platformization entails (Leszczynski, 2016). 
As noted above, platform mobility as a mode of government is characterized by the production of flexible subjects. As Jennifer Gabrys argues, in the context of "smart city" planning, governmentality here is less about producing governable individuals than about producing subjects whose activities generate the data used to govern (2014). In this respect, flexible subjects are not just the ideal consumers of mobility platform services, they are the necessary inputs for optimizing the algorithms that coordinate these platforms. This is not just true of data capital, infrastructural capital, and motordom, whose accumulation strategies are predicated on such subjects. The public planning efforts behind services like Polygo and MaaS Madrid also depend on the activities of users, and the data they generate, as key elements of the infrastructures themselves, whether as consumers, workers, or some combination of the two.

\section{A fragile spatial fix}

In the broadest sense, mobility platforms raise a number of issues regarding their place in the long-term evolution of capitalism. For Harvey, the defining feature of large infrastructure projects as a "spatial fix" for capital is that they absorb overaccumulated capital surpluses and return their value to the accumulation process over a longer time horizon than the actions of any single firm. Yesterday's spatial fixes become today's public assets, but also tomorrow's frontiers of marketization, its own form of spatial fix (Harvey, 2006). But after several decades of privatization, the "low-hanging fruit" of transport marketization-bus and train privatization, toll road conversion, etc. - has been significantly depleted.

With this in mind, platformization constitutes a distinct - and arguably more fragile - spatial fix (or a mobility fix, as Spinney, 2016 puts it), uniting two core pressures in contemporary political economy. The first is the emergence of data-centered accumulation strategies, fed by the increasing instrumentation of mobility patterns and the algorithmic processing of the data they generate. The second is the need to absorb overaccumulated capital into new infrastructures, in this case infrastructures for the production of this data. The platformization of mobility thus unlocks new sources of value-evidenced by the massive valuations in the sector-without the risk and slow pace of building up fixed assets. When new assets are needed, such as with micromobility platforms like Lime, they tend to be inexpensive, largely disposable, or, as in the case of motordom, something the firms in question already produce. For infrastructural capital, there may be more risk involved in extending beyond core functions like bus and train operation, but even platforms like Deutsche Bahn's Ioki that deploy sophisticated autonomous shuttles pale in investment terms compared to its broader capital base (Deutsche Bahn, 2019).

In sum, while previous such spatial fixes built durable infrastructures (railroads, highways, fiber optic cables, etc.) that guided development over the long term, the current wave of "lean" platforms are largely interstitial and ephemeral, rather than transformative, realized in the gaps between the scale of central city walking and that of region-serving commute infrastructure. 
They exploit a temporal gap as well, that between the current organization of mobilityparticularly the deep, unsustainable strains on automobility — and the infrastructural investments required for a more sustainable urban future. The "code is the new concrete" narrative posits that what the platform architecture firms are developing is the infrastructural base for this future, but the current bubble-prone and proprietary approach, led by data capital, does not inspire confidence. Some responses by infrastructural capital, the public sector, and even motordom may offer a more stable footing, but even these fall far short of the reorganization of the built environment so desperately needed in so many places. And while communities of consciousness generate new forms of platform-mediated solidarity, they continue to face scaling issues that may prevent them from weathering the inevitable contraction of the industry.

\section{Conclusion}

The goal of this paper has been to detail what we see as key tendencies within the process of platformization by focusing on the distinct social interests and institutions involved in platform formation, based on the qualitative database that we have developed. As noted above, we do not mean to imply that the infrastructures, geographies, and politics of platforms can be "read off" from their political-economic origins. However, as platforms constantly mutate-expanding to new markets, offering new services, articulating with existing sociotechnical structures in new ways, and producing new kinds of spaces - tracking these mutations, rather than detailing the forcing conditions behind them, would risk getting lost in the very presentism that is endemic of much coverage of the industry. Focusing on interests also highlights the diversity of actors, particularly governments and cooperatives, which are largely occluded by the business press coverage.

An urban mobility lens likewise offers a distinct perspective on the urbanization of platform capitalism. While the story of the "Big Four"-Amazon, Apple, Facebook, and Google-tends to emphasize the way they have implacably overtaken the information landscape, urban mobility platforms instead highlight the frictional de/reterritorialization of capital. Urban mobility platforms articulate with localized configurations of political-economic power, territorial authority, infrastructural history, and socio-spatial inequality. It is because they are spatially embedded that they cannot simply wipe these out and begin with a tabula rasa. Perhaps, then, this explains the tendency for firms like Alphabet to imagine idealized spaces built "from the internet up," laboratories that eliminate the inconveniences of history and geography (Mattern, 2017). While these dreams may possess certain actors, most mobility is built up on layers of infrastructure, governance, and everyday practice. This friction is enormously productive (Tsing, 2004), generating new practices, spatial forms, and inequalities - as well as diverse efforts to create alternate platform mobilities. 
Our final point is about the urban politics of platforms. The motivation behind the construction of this database has been to go beyond the most high-profile platforms like Uber, Mobike, or CityMapper to examine the wider landscape of how platforms aim to reconfigure urban transport services. This is in response to what we see as a deficit of understanding, particularly at the local government level, of the strategic interests of platform firms, particularly those led by data capital. We also see a deficit of deployment of the types of digital technologies that could genuinely improve urban service provision, as these innovations are largely spearheaded by the private market, leading to an uneven geography of saturation in some places and exclusion in others - both within and across cities. In this respect, more publicly-oriented and cooperative platform mobilities deserve both scrutiny and support, with the goal of contributing to their continued mutation toward more redistributive ends. 


\section{References}

Attoh K, Wells K and Cullen D (2019) "We're building their data": Labor, alienation, and idiocy in the smart city. Environment and Planning D: Society and Space 37(6): 1007-1024.

Barns S (2016) Mine your data: open data, digital strategies and entrepreneurial governance by code. Urban Geography 37(4): 554-571.

Barns S, Cosgrave E, Acuto M, et al. (2017) Digital Infrastructures and Urban Governance. Urban Policy and Research 35(1): 20-31.

Bliss L (2018) Uber Pivots to On-Demand Everything. CityLab, 11 April. Available at: https://www.citylab.com/transportation/2018/04/uber-pivots-to-on-demandeverything/557528/ (accessed 21 June 2018).

Brail S (2017) Promoting innovation locally: Municipal regulation as barrier or boost? Geography Compass 11(12): 1-12.

Bratton BH (2015) The Stack: On Software and Sovereignty. Cambridge, Mass.: MIT Press.

Brenner N and Schmid C (2015) Towards a new epistemology of the urban? City 19(2-3): 151182.

Brown W (2015) Undoing the Demos: Neoliberalism's Stealth Revolution. Zone Books.

Business Wire (2016) Ford Smart Mobility LLC Established to Develop, Invest in Mobility Services; Jim Hackett Named Subsidiary Chairman. 11 March. Available at: https://www.businesswire.com/news/home/20160311005431/en/Ford-Smart-Mobility-LLCEstablished-Develop-Invest (accessed 12 June 2019).

Clewlow RR and Mishra GS (2017) Disruptive Transportation: The Adoption, Utilization, and Impacts of Ride-Hailing in the United States. Available at: http://usa.streetsblog.org/wpcontent/uploads/sites/5/2017/10/2017_UCD-ITS-RR-17-07.pdf (accessed 8 July 2019).

Cresswell T (2010) Towards a politics of mobility. Environment and Planning D: Society and Space 28(1): 17-31.

Crist P (2018) Encoding 21st Century Transport: Toward Algorithmic Policy-Making. In: Annual POLIS Conference: 'Innovation in Transport for Sustainable Cities and Regions', 2018. Available at:

https://www.polisnetwork.eu/uploads/Modules/PublicDocuments/encoding-21st-centurytransport---towards-algorithmic-policy-making-philippe-crist.pdf (accessed 8 December 2018).

Daimler North America (2018) BMW Group and Daimler AG plan next steps for joint mobility company. Available at: https://www.prnewswire.com/news-releases/bmw-group-anddaimler-ag-plan-next-steps-for-joint-mobility-company-competition-authorities-approvemerger-of-mobility-services-300768865.html (accessed 12 June 2019).

Derickson K (2018) Masters of the universe. Environment and Planning D: Society and Space 36(3): 556-562.

Deutsche Bahn (2019) Deutsche Bahn Integrated Interim Report, January-June 2019: Germany needs a strong rail system. Available at: https://ir.deutschebahn.com/fileadmin/Englisch/2019e/Anhaenge/ZB19_e_Web_03.pdf.

Edensor T (2011) Commuter: Mobility, Rhythm and Commuting. Cresswell T and Merriman $\mathrm{P}$ (eds). Surrey: Ashgate.

Egan M (2019) Banker gives inside look at why Uber and Lyft IPOs failed to live up to the hype. CNN Business, 24 May. Available at: https://edition.cnn.com/2019/05/24/investing/uberlyft-stock-ipo-market/index.html (accessed 12 June 2019). 
Elwood S and Leszczynski A (2011) Privacy, reconsidered: New representations, data practices, and the geoweb. Geoforum 42(1): 6-15.

Foucault M (2009) Security, Territory, and Population: Lectures at the Collège de France, 19771978. Burchell G and Senellart M (eds). New York: Picador.

Gabrys J (2014) Programming Environments: Environmentality and Citizen Sensing in the Smart City. Environment and Planning D: Society and Space 32(1): 30-48.

Gibson-Graham J (2006) The End of Capitalism (As We Knew It): A Feminist Critique of Political Economy. Minneapolis, MN: University of Minnesota Press.

Graham S and Marvin S (2001) Splintering Urbanism: Networked Infrastructures, Technological Mobilities and the Urban Condition. New York: Routledge.

Gregg M (2015) Inside the Data Spectacle. Television \& New Media 16(1): 37-51.

Grengs J (2005) The abandoned social goals of public transit in the neoliberal city of the USA. City 9(1): 51-66.

Hanna R, Kuhnert F and Kiuchi H (2015) Re-inventing the wheel: Scenarios for the transformation of the automotive industry. Available at: http://www.pwc.com/gx/en/industries/automotive/publications/reinventing-the-wheel.html.

Hannam K, Sheller M and Urry J (2006) Editorial: Mobilities, Immobilities and Moorings. Mobilities 1(1): 1-22.

Harvey D (1989) From Managerialism to Entrepreneurialism: The Transformation in Urban Governance. Geografiska Annaler 71(1): 3-17.

Harvey D (2006) Limits to Capital. London: Verso.

Hecker M, Zhou Q and Wu Z (2018) The Future of Shared Mobility in China. Deloitte Perspective. Available at:

https://www2.deloitte.com/content/dam/Deloitte/cn/Documents/about-deloitte/dttp/deloittecn-dttp-vol7-ch3-future-of-shared-travel-en.pdf.

Henley J (2017) Uber clashes with regulators in cities around the world. The Guardian, 29 September. Available at: https:/www.theguardian.com/business/2017/sep/29/uber-clasheswith-regulators-in-cities-around-the-world (accessed 12 June 2019).

Hodson M and Marvin S (2010) Urbanism in the anthropocene: Ecological urbanism or premium ecological enclaves? City 14(3): 298-313.

Hommels A (2005) Unbuilding Cities: Obduracy in Urban Socio-Technical Change. Cambridge MA: MIT Press.

Huang Z (2017) WeChat is morphing so Chinese smartphone owners will never have to download an app again. Quartz, 10 January. Available at: https://qz.com/880926/wechat-ismorphing-so-chinese-smartphone-owners-will-never-have-to-download-an-app-again/ (accessed 11 June 2019).

International Energy Agency (n.d.) CO2 Emissions Statistics. Available at: https://www.iea.org/statistics/co2emissions/ (accessed 11 June 2019).

Kanter J (2019) Uber's disclosure that it may never be profitable coincides with the return of a danger-signal from the dot-com crash. Business Insider, 12 April. Available at: https://www.businessinsider.com/ubers-ipo-prospectus-says-it-may-never-be-profitable2019-4 (accessed 11 June 2019).

Kitchin R (2014) The real-time city? Big data and smart urbanism. GeoJournal 79: 1-14. Lacy P and Rutqvist J (2015) Waste to Wealth: The Circular Economy Advantage. New York: Palgrave Macmillan.

Langley P and Leyshon A (2017) Platform capitalism: the intermediation and capitalization of 
digital economic circulation. Finance and Society 3(1): 11-31.

Lee T (2016) Grab's 2015 financial numbers revealed. Tech In Asia, 1 August. Available at: https://www.techinasia.com/grabs-2015-financial-numbers-revealed-rivalry-uber (accessed 12 June 2019).

Leininger E (2018) What Does the 'Wall of Money' Mean for Your Investments? Bloomberg, 7 February. Available at: https:/www.bloomberg.com/news/articles/2018-02-07/what-doesthe-wall-of-money-mean-for-your-investments (accessed 2 February 2019).

Leriche Y and Teale C (2018) Transdev's North America CEO on AVs, transit and lessons from Europe. Smart Cities Dive, 21 November. Available at:

https://www.smartcitiesdive.com/news/Yann-Leriche-transdev-north-america-ceo-avstransit-europe/542779/ (accessed 12 June 2019).

Leszczynski A (2016) Speculative futures: Cities, data, and governance beyond smart urbanism. Environment and Planning A 48(9): 1691-1708.

Lorenz T (2018) Electric Scooter Charger Culture Is Out of Control. The Atlantic, 20 May. Available at: https://www.theatlantic.com/technology/archive/2018/05/charging-electricscooters-is-a-cutthroat-business/560747/ (accessed 12 June 2019).

Marvin S and Luque-Ayala A (2017) Urban Operating Systems: Diagramming the City. International Journal of Urban and Regional Research 41(1): 84-103.

Massey D (1994) Space, Place, and Gender. Minneapolis, MN: University of Minnesota Press.

Mattern S (2017) A City Is Not a Computer. Places Journal (2017). Available at: https://placesjournal.org/article/a-city-is-not-a-computer/ (accessed 4 November 2019).

Mazzucato M (2014) The Entrepreneurial State: Debunking Public vs. Private Sector Myths. London: Anthem.

McIntyre N and Kollewe J (2019) Life cycle: is it the end for Britain's dockless bike schemes? The Guardian UK, 22 February. Available at: https://www.theguardian.com/cities/2019/feb/22/life-cycle-is-it-the-end-for-britainsdockless-bike-schemes (accessed 28 March 2019).

Ministry of Transport and Communications (2018) Act on Transport Services to cover the entire transport system. 27 April. Available at: https://www.lvm.fi/-/act-on-transport-services-tocover-the-entire-transport-system-971134 (accessed 12 June 2019).

New Economics Foundation (2017) We can do better than Uber. 12 May. Available at: https://neweconomics.org/2017/05/cabfair (accessed 12 June 2019).

Nolan S (2015) Burn Rate Doesn't Matter. TechCrunch, 5 April. Available at: https://techcrunch.com/2015/04/05/burn-rate-doesnt-matter/ (accessed 3 November 2019).

North American Bikeshare Assocation (2018) Subject: NABSA Code of Conduct Complaint Investigation: Final Board Determination. 21 March. Available at: https://nabsa.net/wpcontent/uploads/2017/09/Ofo-Final-letter-3-21-18.docx-1.pdf (accessed 14 June 2018).

Norton PD (2011) Fighting Traffic: The Dawn of the Motor Age in the American City. Cambridge MA: The MIT Press.

Oswin N (2018) Planetary urbanization: A view from outside. Environment and Planning D: Society and Space 36(3): 540-546.

Peck J and Theodore N (2007) Variegated capitalism. Progress in Human Geography 31(6): 731-772.

Peck J and Tickell A (2002) Neoliberalizing Space. Antipode 34(3): 380-404.

Pojani D and Stead D (2017) The urban transport crisis in emerging economies. In: Pojani D and Stead D (eds) The Urban Transport Crisis in Emerging Economies. Cham, Switzerland: 
Springer, pp. 1-10.

Reid C (2019) Netflix-Of-Transportation App Reduces Car Use And Boosts Bike And Bus Use, Finds MaaS Data Crunch. Forbes, 28 March. Available at: https://www.forbes.com/sites/carltonreid/2019/03/28/netflix-of-transportation-app-reducescar-use-and-boosts-bike-and-bus-use-finds-maas-data-crunch/\#56673e854923 (accessed 12 June 2019).

Robinson J (2006) Ordinary Cities: Between Modernity and Development. New York; London: Routledge.

Robinson J and Roy A (2016) Debate on Global Urbanisms and the Nature of Urban Theory. International Journal of Urban and Regional Research 40(1): 181-186.

Rushe D (2019) Stampede of the unicorns: will a new breed of tech giants burst the bubble? The Guardian, 30 March. Available at:

https://www.theguardian.com/technology/2019/mar/30/lyft-ipo-stock-market-unicornsuber-airbnb-slack (accessed 12 June 2019).

Sadowski J (2019) When data is capital: Datafication, accumulation, and extraction. Big Data \& Society 6(1): 1-12.

Schmitt A (2018) The Story of "Micro Transit" Is Consistent, Dismal Failure. Streetsblog, 26 June. Available at: https://usa.streetsblog.org/2018/06/26/the-story-of-micro-transit-isconsistent-dismal-failure/ (accessed 12 June 2019).

Scholz T (2016) Platform Cooperativism: Challenging the Corporate Sharing Economy.

Schwanen T (2016) Geographies of transport I. Progress in Human Geography 40(1): 126-137.

Sender H (2019) Go-Jek and Grab's competing visions play out. Financial Times, 24 April. Available at: https://www.ft.com/content/fb92f4a0-64f0-11e9-9adc-98bfld35a056 (accessed 11 June 2019).

Shameen A (2017) Will Uber, Grab and Didi ever make money? The Edge Singapore, 22 August. Available at: https://www.theedgesingapore.com/will-uber-grab-and-didi-evermake-money (accessed 12 June 2019).

Sheller M and Urry J (2006) The new mobilities paradigm. Environment and Planning A 38(2): 207-226.

Sheller MB and Urry J (2000) The City and the Car. International Journal of Urban and Regional Research 24(4): 737-757.

Sherriff G, Adams M, Blazejewski L, et al. (2018) Bike share in Greater Manchester Bike Share in Greater Manchester. Available at: http://usir.salford.ac.uk/48658/8/2018 Sherriff et al Bike Share in Greater Manchester.pdf (accessed 26 November 2018).

Siemiatycki M (2011) Urban transportation public-private partnerships: Drivers of uneven development? Environment and Planning A 43(7): 1707-1722.

Silver J (2014) Incremental infrastructures: Material improvisation and social collaboration across post-colonial Accra. Urban Geography 35(6): 788-804.

Smith N (1984) Uneven Development: Nature, Capital and the Production of Space. Oxford: Blackwell.

Smith N (1992) Contours of a Spatialized Politics: Homeless Vehicles and the Production of Geographical Scale. Social Text 33(33): 54-81.

Somerville H (2019) The answer to Uber's profit challenge? It may lie in its trove of data. Reuters, 9 May. Available at: https://www.reuters.com/article/us-uber-ipo-profit/theanswer-to-ubers-profit-challenge-it-may-lie-in-its-trove-of-data-idUSKCN1SF0O5 (accessed 3 November 2019). 
South China Morning Post (2018) Bike-sharing firm Ofo's dramatic fall from grace a warning to China's tech investors. Available at: https://www.scmp.com/tech/startups/article/2179485/bike-sharing-firm-ofos-dramatic-fall-grace-warning-chinas-tech (accessed 12 June 2019).

Spinney J (2016) Fixing Mobility in the Neoliberal City: Cycling Policy and Practice in London as a Mode of Political-Economic and Biopolitical Governance. Annals of the American Association of Geographers 106(2): 450-458.

Srnicek N (2016) Platform Capitalism. London: Polity.

St. John A (2019) Car2Go the latest short-term car rental service to pull out of major U.S. cities. Crain's Chicago Business, 27 September. Available at:

https://www.chicagobusiness.com/transportation/car2go-latest-short-term-car-rentalservice-pull-out-major-us-cities (accessed 11 November 2019).

Storper M and Scott AJ (2016) Current debates in urban theory: A critical assessment. Urban Studies 53(6): 1114-1136.

Storper M and Walker RA (1989) The Capitalist Imperative. New York; Oxford: Basil Blackwell.

Sullivan T (2016) Blitzscaling. Harvard Business Review, April. Available at: https://hbr.org/2016/04/blitzscaling.

Sundarajan A (2016) The Sharing Economy: The End of Employment and the Rise of CrowdBased Capitalism. Cambridge, MA and London: MIT Press.

Taylor A (2015) The People's Platform: Taking Back Power and Culture in the Digital Age. New York: Picador.

Thatcher J, O'Sullivan D and Mahmoudi D (2016) Data colonialism through accumulation by dispossession: New metaphors for daily data. Environment and Planning D: Society and Space 34(6): 990-1006.

The Economist (2018) The hidden cost of congestion. 28 February. Available at: https://www.economist.com/graphic-detail/2018/02/28/the-hidden-cost-of-congestion (accessed 11 June 2019).

The Economist (2019) Tech's new stars have it all-except a path to high profits. 17 April. Available at: https://www.economist.com/leaders/2019/04/17/techs-new-stars-have-it-allexcept-a-path-to-high-profits (accessed 12 June 2019).

Tsing AL (2004) Friction: An Ethnography of Global Connection. Princeton, NJ: Princeton University Press.

Turner F (2008) From Counterculture to Cyberculture: Stewart Brand, the Whole Earth Network, and the Rise of Digital Utopianism. Chicago: University Of Chicago Press.

van Dijck J, Poell T and de Waal M (2018) The Platform Society: Public Values in a Connective World. Oxford: Oxford University Press.

Wiig A (2016) IBM's smart city as techno-utopian policy mobility. City 19(2-3): 192-207.

Wilhelm A (2019) Soon, Everything Will Be A Scooter Startup. Crunchbase News, 22 January. Available at: https://news.crunchbase.com/news/soon-everything-will-be-a-scooter-startup/ (accessed 28 March 2019).

Wilson MW (2012) Location-based services, conspicuous mobility, and the location-aware future. Geoforum 43(6): 1266-1275.

Winner L (1989) The Whale and the Reactor: A Search for Limits in an Age of High Technology. University Of Chicago Press.

Zuboff S (2015) Big other: Surveillance capitalism and the prospects of an information 
civilization. Journal of Information Technology 30(1): 75-89. 


\section{Fig. 1: A typology of platform trajectories}

\begin{tabular}{|c|c|c|c|c|c|}
\hline & $\begin{array}{c}\text { Networked } \\
\text { accumulation }\end{array}$ & $\begin{array}{l}\text { Infrastructural } \\
\text { thickening }\end{array}$ & Life extension & Governmental fix & Commoning \\
\hline 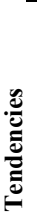 & $\begin{array}{l}\text { Exploit existing mobility } \\
\text { gaps, both appropriating } \\
\text { existing informal mobility } \\
\text { practices and "under- } \\
\text { utilized" assets as well as } \\
\text { introducing new } \\
\text { instrumented vehicles into }\end{array}$ & $\begin{array}{l}\text { Incumbent large } \\
\text { infrastructure firms } \\
\text { expanding into mobility } \\
\text { services to complement } \\
\text { existing transport } \\
\text { operations }\end{array}$ & $\begin{array}{l}\text { Incumbent automobility } \\
\text { firms investing in shared } \\
\text { vehicle fleets as "exit } \\
\text { strategy" from declining } \\
\text { auto sales and preparation } \\
\text { for autonomous vehicles }\end{array}$ & $\begin{array}{l}\text { State agencies (EU, } \\
\text { regional, municipal) and } \\
\text { civil society/non-profit } \\
\text { organizations with goals } \\
\text { of promoting social values } \\
\text { and local economic } \\
\text { competitiveness }\end{array}$ & $\begin{array}{l}\text { Formation of } \\
\text { crowdfunded platforms } \\
\text { for peer to peer (P2P) } \\
\text { services, typically in } \\
\text { reaction to market power } \\
\text { of large platforms (Uber, } \\
\text { etc.) }\end{array}$ \\
\hline
\end{tabular}

\begin{tabular}{|c|c|c|c|c|c|}
\hline \multirow{7}{*}{$\frac{\frac{\pi}{0}}{\bar{B}}$} & Uber & DB Flinkster & Car2Go & Kyyti & Eva \\
\hline & Didi Chuxing & Acciona Mobility & Reachnow & Kutsuplus & Cotabo \\
\hline & Bird & Ioki & CleverShuttle & MaaSMadrid & Commu.ne \\
\hline & GO-JEK & Whim & GIG & Polygo & Swarm City \\
\hline & SafeBoda & Navly & Moia & Remix & Modo \\
\hline & CityMapper & & Moovel & Afta Robot & RideAustin \\
\hline & Gett & & Spin & Beijing 96106 & \\
\hline
\end{tabular}

\begin{tabular}{llll}
\hline Data capital & Infrastructural capital & Motordom & Public capital \\
Tencent Holdings & Acciona & Daimler & European Union \\
Alibaba Capital & Keolis & BMW & Regional governments \\
consciousness Cooperative federations \\
Softbank & Deutsche Bahn & Volkswagen & Local transport authorities Social entrepreneurship \\
Andreesen Horowitz & Transdev & Indigo & State innovation funds \\
Temasek Holdings & & Europcar & Local tech accelerators
\end{tabular}

\begin{tabular}{|c|c|c|c|c|}
\hline $\begin{array}{l}\text { "Asset-light" with } \\
\text { minimal infrastructure, } \\
\text { consisting of } \\
\text { users'/providers' own } \\
\text { vehicles/ assets or new } \\
\text { inexpensive vehicles, } \\
\text { smartphone based with } \\
\text { location services }\end{array}$ & $\begin{array}{l}\text { Fleets of shared vehicles } \\
\text { extending "last mile" of } \\
\text { mass transport nodes, as } \\
\text { well as integrated } \\
\text { ticketing and route } \\
\text { planning under "mobility- } \\
\text { as-a-service" }\end{array}$ & $\begin{array}{l}\text { Fleets of shared cars, tend } \\
\text { to coordinate with } \\
\text { housing and commercial } \\
\text { development; "floating" } \\
\text { systems can be parked } \\
\text { anywhere within service } \\
\text { area }\end{array}$ & $\begin{array}{l}\text { Tend to be more } \\
\text { integrative/coordinating, } \\
\text { creating all-in-one } \\
\text { "mobility-as-a-service" } \\
\text { portals; in global South, } \\
\text { have a formalizing } \\
\text { function, integrating } \\
\text { informal jitney/taxi } \\
\text { services into formal } \\
\text { economy }\end{array}$ & $\begin{array}{l}\text { True P2P approach, } \\
\text { tendencies toward } \\
\text { distributed, decentralized, } \\
\text { horizontal structures, thus } \\
\text { relying on existing } \\
\text { infrastructures and } \\
\text { participants' own assets }\end{array}$ \\
\hline
\end{tabular}

\begin{tabular}{|c|c|c|c|c|c|}
\hline & $\begin{array}{l}\text { Scale shaped by size of } \\
\text { potential market, gaps in } \\
\text { existing infrastructure, } \\
\text { and potential to reshapes/ } \\
\text { marketize existing } \\
\text { practices }\end{array}$ & $\begin{array}{l}\text { Services more directly } \\
\text { coordinated with mass } \\
\text { transport, adding density } \\
\text { to existing infrastructure }\end{array}$ & $\begin{array}{l}\text { Shift to "floating" systems } \\
\text { produces scale determined } \\
\text { by market demand, less } \\
\text { extensive than with } \\
\text { infrastructural capital, } \\
\text { more directly competitive } \\
\text { with mass transport }\end{array}$ & $\begin{array}{l}\text { Tend to operate at city- } \\
\text { regional scale, integrating } \\
\text { both public and private } \\
\text { services, often through } \\
\text { partnerships that extend } \\
\text { existing mass transport } \\
\text { into lower-density outer } \\
\text { areas through demand- } \\
\text { responsive shuttles }\end{array}$ & $\begin{array}{l}\text { Relatively small-scale } \\
\text { initiatives, often place- } \\
\text { based, or federated via } \\
\text { blockchain technology, } \\
\text { but in principle follow } \\
\text { solidarity economies, face } \\
\text { to face markets, or direct } \\
\text { democracy principles }\end{array}$ \\
\hline 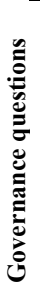 & $\begin{array}{l}\text { Rapid launch/closure, } \\
\text { often hostile to regulation, } \\
\text { evasive about data } \\
\text { sharing, etc., avoiding } \\
\text { direct coordination with } \\
\text { existing governance } \\
\text { institutions }\end{array}$ & $\begin{array}{l}\text { More coordinated with } \\
\text { existing infrastructures } \\
\text { and government } \\
\text { partnerships, API } \\
\text { integration with public } \\
\text { transport, etc. }\end{array}$ & $\begin{array}{l}\text { Storing vehicles in public } \\
\text { right of way requires more } \\
\text { collaboration to secure } \\
\text { parking areas/permissions, } \\
\text { charging stations for EVs, } \\
\text { etc. }\end{array}$ & $\begin{array}{l}\text { Often explicitly developed } \\
\text { to achieve particular } \\
\text { governance goals, } \\
\text { especially improvement of } \\
\text { public services and } \\
\text { proactive management of } \\
\text { disruptive technologies }\end{array}$ & $\begin{array}{l}\text { Decentralized governance } \\
\text { approach, either through } \\
\text { direct democracy or } \\
\text { blockchain-based } \\
\text { validation, often } \\
\text { ideologically based on } \\
\text { citizenship rather than } \\
\text { control principles }\end{array}$ \\
\hline
\end{tabular}




\section{Notes}

${ }^{1}$ The range of APIs and data ontologies within platforms was not included in the analysis, except in cases where mobility platforms commercialized these software elements to become software-as-a-service providers. We thank one of the anonymous reviewers for raising this point.

${ }^{2}$ These were further aggregated into the Free Now MaaS platform under the Daimler-owned Moovel label, which incorporates car-sharing, ride-hailing, mass transport booking, and parking platforms, some owned by Daimler (ReachNow, ParkNow) and others incorporated as strategic partners (MyTaxi, Beat). See: https://www.your-now.com/our-story.

${ }^{3}$ This is not a judgment about their inherently more public nature, only that they deploy public resources in a variety of ways to support or shape the platform economy. 